This is the authors' copy of the final unpublished version of this manuscript. The Version of Record is available at:

https://doi.org/10.1016/j.cognition.2019.104045

Please cite as:

Ziegler, J., Bencini, G., Goldberg, A., \& Snedeker, J. (2019). How abstract is syntax? Evidence from structural priming. Cognition, 193, 104045.

\title{
How abstract is syntax? Evidence from structural priming
}

\author{
Jayden Ziegler ${ }^{1}$, Giulia Bencini ${ }^{2}$, Adele Goldberg $^{3}$, \& Jesse Snedeker ${ }^{1}$ \\ ${ }^{1}$ Department of Psychology, Harvard University \\ ${ }^{2}$ Department of Linguistics and Comparative Cultural Studies, Ca' Foscari University of Venice \\ ${ }^{3}$ Department of Psychology, Princeton University
}

Jayden Ziegler (corresponding)

Dept. of Psychology

Harvard University

33 Kirkland St.

Cambridge, MA 02138

(908) 548-3384

ziegler@g.harvard.edu 


\begin{abstract}
In 1990, Bock and Loebell found that passives (e.g., The 747 was radioed by the airport's control tower) can be primed by intransitive locatives (e.g., The 747 was landing by the airport's control tower). This finding is often taken as strong evidence that structural priming occurs on the basis of a syntactic phrase structure that abstracts across lexical content, including prepositions, and is uninfluenced by the semantic roles of the arguments. However, all of the intransitive locative primes in Bock and Loebell contained the preposition by (by-locatives), just like the passive targets. Therefore, the locative-to-passive priming may have been due to the adjunct headed by by, rather than being a result of purely abstract syntax. The present experiment investigates this possibility. We find that passives and intransitive $b y$-locatives are equivalent primes, but intransitive locatives with other prepositions (e.g., The 747 has landed near the airport control tower) do not prime passives. We conclude that a shared abstract, content-less tree structure is not sufficient for passive priming to occur. We then review the prior results that have been offered in favor of abstract tree priming, and note the range of evidence can be considerably narrowed — and possibly eliminated — once effects of animacy, semantic event structure, shared morphology, information structure, and rhythm are taken into account. Keywords: abstract syntax; structural priming; syntactic priming; passive alternation
\end{abstract}




\section{Introduction}

When we speak to one another, we must take our ideas (our messages), convert them into words, and combine those words to form utterances. It is easy to conceive of the lexical and combinatorial processes as separable, and many early linguistic and psycholinguistic models argued that words and syntax were generated by wholly distinct systems (Chomsky, 1994; Frazier \& Fodor, 1978). At the same time, we have long recognized that lexical and syntactic representations are often intimately related, with each representation constraining the other (Chomsky, 1965; Culicover, 1999; Fillmore, 1968; Jackendoff, 1975; Lakoff, 1970; Levelt, 1993; MacDonald, Pearlmutter, \& Seidenberg, 1994; Trueswell, Tanenhaus, \& Garnsey, 1994).

One powerful tool used to explore the relationship between word choice and syntactic structure has been structural priming, which describes the tendency for speakers to reuse previously encountered sentence structures (Bock, 1986; for meta-analysis and reviews, see Branigan, 2007; Branigan \& Pickering, 2017; Ferreira \& Bock, 2006; Mahowald, James, Futrell, \& Gibson, 2016; Pickering \& Ferreira, 2008; Tooley \& Traxler, 2010; Traxler \& Tooley, 2012). For instance, Bock (1986) showed that speakers were more likely to describe a picture with a todative (e.g., The man is reading a story to the boy) after using a different to-dative (e.g., A rock star sold some cocaine to an undercover agent) than after using a double-object dative (A rock star sold an undercover agent some cocaine). Within the structural priming literature, there is evidence that structural priming is increased when the prime and target sentences share a content word (i.e., the lexical boost; Cleland \& Pickering, 2003; Pickering \& Branigan, 1998). But we know that structural priming occurs even when prime and target do not overlap in content or function words (Bock, 1986, 1989). 
Critically, structural priming has been argued to only require shared abstract syntax, occurring even in the absence of shared argument types (semantic roles), shared discourserelated properties, or shared words (Bock, 1986, 1989; Bock \& Loebell, 1990). In other words, structural priming has been thought to reflect the priming of abstract, content-less tree structures (for discussion, see Branigan, 2007; Branigan \& Pickering, 2017; Branigan, Pickering, Liversedge, Stewart, \& Urbach, 1995; Chang, Dell, \& Bock, 2006). For this reason, the effect is often referred to as syntactic priming, rather than the more neutral term, structural priming, that we adopt here.

A key piece of evidence that has been used to argue in favor of fully abstract syntactic priming is, on closer examination, ambiguous. Bock and Loebell (1990, Exp. 2) found that participants produced as many passive sentences following intransitive locative sentences (The 747 was landing by the airport's control tower) as they did after other passives (The 747 was alerted by the airport's control tower). While passives and intransitive locatives appear to share the same abstract syntax (following, e.g., Emonds, 1976; though see section 4.1 for alternative analyses), their semantics is clearly distinct. In a passive sentence like The 747 was alerted by the airport's control tower, the control tower is the actor of the action and the 747 is the undergoer of the action; in the intransitive locative, The 747 was landing by the airport's control tower, the 747 is the argument that is acting and the control tower is a location. Thus, this data point seems to demonstrate that abstract phrase structures can be primed. This study, however, contains a lexical confound: All of the intransitive locative primes contained the preposition by and the auxiliary be, just like the passive targets, while none of the actives did. Therefore, the locative-to-passive priming that was found may have been due, in part or in whole, to the shared 
lexical material. ${ }^{1}$ If locative-to-passive priming requires lexical overlap, it would remove the strongest evidence we have that priming can occur on the basis of fully abstract syntactic representations (for discussion, see, e.g., Desmet \& Declercq, 2006; Ferreira, 2003; Goldberg, 2006, ch. 6.10; Hare \& Goldberg, 1999; Hartsuiker, Kolk, \& Huiskamp, 1999, fn. 3). Bock and Loebell (1990) acknowledged this concern. Their conclusion that the locus of this priming was purely syntactic rested on evidence from another construction and the assumption that all argument structure alternations are primed in the same way.

Specifically, Bock (1989) had shown previously that for-datives (e.g., The secretary is baking a cake for her boss) are just as good at eliciting to-dative target descriptions (e.g., The girl is handing the paintbrush to the man on the ladder) as other to-dative primes (e.g., The secretary is taking a cake to her boss; see also Chang, Bock \& Goldberg, 2003; Ziegler \& Snedeker, 2018). For-to-to-dative priming, however, is also ambiguous. Critically, the two dative constructions have common semantic properties which could be responsible for the priming. Specifically, the semantic event structures ascribed to to-datives and for-datives are closely related (e.g., Jackendoff, 1972, 1983; Lakoff \& Johnson, 1980), and critically, are distinct from the semantic event structure of double-object datives, which is the same regardless of whether the sentences can be paraphrased using to or for (Goldberg, 2002; Green, 1974). At the time Bock and Loebell (1990) presented their findings, there was no evidence that semantic event structure could be primed. Now, however, there is ample evidence for this form of priming in dative and closely related constructions (see, e.g., Cai, Pickering, \& Branigan, 2012; Chang et

\footnotetext{
${ }^{1}$ Likewise, Messenger, Branigan, McLean, and Sorace (2012) found that children (ages 3-4) and adults produced more passives after passives that were quite different semantically. In particular, they found that children were more likely to produce undergoer-agent passives (e.g., A girl is being hit by a sheep) after experiencer-theme passives (e.g., A girl is being shocked by a sheep) than after actives. Putting aside the possibility that in both cases causer and theme arguments might be involved, all of the primes again included the word $b y$.
} 
al., 2003; Cho-Reyes, Mack, \& Thompson, 2016; Hare \& Goldberg, 1999; Köhne, Pickering, \& Branigan, 2014; Pappert \& Pechmann, 2014; Salamoura \& Williams, 2007; Yi \& Koenig, 2016; Ziegler \& Snedeker, 2018; Ziegler, Snedeker, \& Wittenberg, 2018).

For example, Chang et al. (2003) found that location-theme locative sentences (e.g., The maid rubbed the table with polish) led to more location-theme responses (e.g., The farmer heaped the wagon with straw), which share a semantic event structure, as compared to themelocation locatives (e.g., The maid rubbed polish onto the table), which have a different semantic event structure (see also Yi \& Koenig, 2016; Ziegler \& Snedeker, 2018; for evidence of locative priming in Brazilian Portuguese, see Ziegler, Morato, \& Snedeker, in press). Critically, this priming occurred independently of syntax and animacy, which were the same across prime types. Similarly, Ziegler et al. (2018) showed that compositional dative primes (e.g., The culprit gives the attorney a check) yielded greater priming on compositional dative targets (e.g., The boy gives the cowboy a rope) than did either idiomatic dative primes (e.g., The audience gives the performer his due) or light verb dative primes (e.g., The boy gives the girl a hug; see also Griffin \& Weinstein-Tull, 2003, for a semantic boost in clausal complement constructions). The compositional dative primes and targets were matched on syntactic phrase structure, semantic event structure, and syntax-animacy mappings, while the idiomatic and light verb dative primes had only the same syntactic phrase structure and syntax-animacy mappings, thus implicating semantic event structure as the locus of the difference in priming (for further discussion of the involvement of event representation in priming, see Ziegler, 2019; Ziegler et al., 2018).

Thus, for-to-to-dative priming cannot distinguish between priming on the basis of syntax and priming based on semantic event structure, or some combination of these factors. ${ }^{2}$ This

\footnotetext{
${ }^{2}$ Alternatively, the for-to-to-dative priming could be the result of animacy priming. We know that the order of animate and inanimate arguments can be primed (Bock, Loebell, \& Morey, 1992; Gámez \& Vasilyeva, 2015;
} 
observation makes it all the more important to determine whether the locative-to-passive priming reported by Bock and Loebell (1990) was truly the result of priming a fully abstract phrase structure, or whether it depended critically on the shared lexical content (the use of by and the same auxiliary, be). Passive-to-passive priming is a well-replicated phenomenon (see Mahowald et al., 2016). However, to the best of our knowledge, no study rules out the lexical hypothesis (including, e.g., Messenger, Branigan, \& McLean, 2011), a point we will elaborate on in the discussion.

The experiment reported in this paper therefore has two primary goals. First, we aimed to replicate Bock and Loebell's (1990, Exp. 2) original finding with a much larger sample of participants and updated statistical tools, as the study has been a theoretical lynchpin in priming research for almost 30 years. Save for the confounding inclusion of by and be, the fact that the intransitive locative condition primed passives has stood as the strongest evidence in favor of fully abstract syntax. And yet we are unaware of any published replications. In addition, and more relevantly for the current discussion, we set out to determine whether the locative-topassive priming in Bock and Loebell (1990) was based, in whole or in part, on shared abstract syntax devoid of lexical content. Specifically, we ask whether passives are primed by intransitive locatives that do not contain the preposition by or the same auxiliary. Therefore, we added a fourth condition to Bock and Loebell's (1990) design: intransitive locatives that did not contain by or be (e.g., The 747 has landed near the airport control tower). If we find that these sentences are equally good primes for passive sentences as intransitive by-locatives, it would provide strong evidence in favor of fully abstract syntax.

Ziegler \& Snedeker, 2018). Such priming could also ensure that to-datives would prime for-datives over the alternative double-object option. 
In the discussion, we situate the current findings in a broader context by reviewing a range of prior work that has argued in favor of abstract syntactic priming. While we do not and cannot rule out the possibility that abstract syntactic priming exists, we suggest that the majority of previous results allow the possibility that the effects reported required shared lexical content, shared semantic event structure, shared information structure, shared prosody. As discussed there, it could be that different factors are more or less relevant for different types of constructions.

\section{Methods}

\subsection{Participants}

300 native English speakers recruited from Amazon Mechanical Turk participated (166 female, 129 male, 4 trans, 1 unreported; mean age=36, $\mathrm{SD}=11$, range=18-73). All participants provided written consent (in accordance with the guidelines of the Committee on the Use of Human Subjects at Harvard University) prior to participating and received $\$ 4.50$ in compensation.

\subsection{Materials}

The study consisted of 32 critical trials interspersed with 68 filler trials, for a total of 100 trials. All trials included a sequence of one prime sentence, presented as text to be read out loud, followed by a target picture, described below. The sentence primes were 32 sets of transitive sentences in each of four priming conditions: full passive (Passive; e.g., The 747 was radioed by the airport control tower), active transitive (Active; e.g., The 747 radioed the airport control tower), intransitive locative with a by-phrase (By-locative; e.g., The 747 was landing by the airport control tower), and intransitive locative with a non-by-phrase (Non-by-locative; e.g., The 
747 has landed near the airport control tower). Some of the intransitive verbs came from the original Bock and Loebell (1990) stimuli; the remainder were chosen with the requirement that they made sense and were grammatical in the intransitive locative construction (with by and at least one other preposition). We represent the structure of active transitive sentences in Fig. 1a, and the structure of the other sentence types, including passive, intransitive $b y$-locative, and intransitive non-by-locative sentences, in Fig. $1 \mathrm{~b}$ (the possibility that the representation in Fig. $1 \mathrm{~b}$ is invalid is addressed in section 4.1). (For a full list of all prime sentences, see Appendix A.).
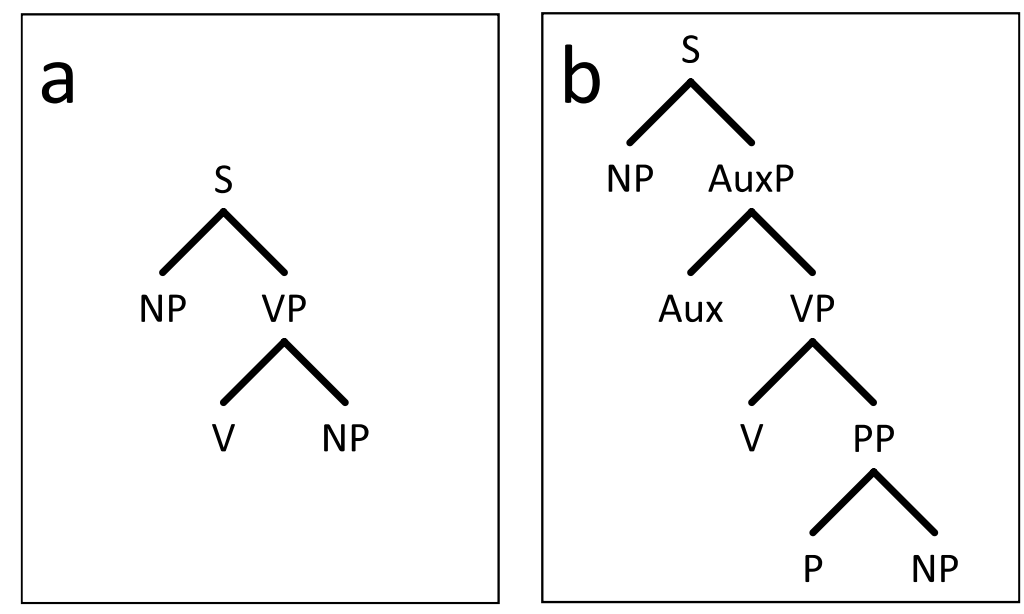

Figure 1. Constituent structure for (a) active transitives and (b) passives or intransitive locatives.

In the Active primes, an agent of the action appeared in the subject NP (e.g., 747), the verb was expressed in past tense in the active voice (e.g., radioed), and a direct object NP contained an undergoer argument (e.g., airport control tower). In the corresponding Passive primes, the undergoer appeared in the subject NP (e.g., 747), the verbal predicate included the auxiliary be and a past participle (e.g., was radioed), and the agent of the action appeared in a PP headed by the preposition by (e.g., by the airport control tower). In the By-locative primes, the agent of the action appeared in the subject NP (e.g., 747), the verbal predicate included the 
auxiliary be and a progressive intransitive verb (e.g., was landing), and the PP contained the locative preposition by followed by the object NP (e.g., by the airport control tower). The semantic role of the oblique noun (e.g., airport control tower) was that of location. Finally, in the Non-by-locative primes, the agent of the action appeared in the subject NP (e.g., 747), the verbal predicate included the auxiliary have and a past participle (e.g., has landed), and the PP was identical to its $B y$-locative counterpart except for the presence of a different preposition (e.g., near the airport control tower vs. by the airport control tower). ${ }^{3} \mathrm{We}$ used be in our By-locatives in order to replicate Bock and Lobell (1990), who also had consistently used be. We used have in our Non-by-locatives in order to make them as similar to passives as possible while eliminating any shared lexical content. See Table 1 for example prime stimuli.

\begin{tabular}{|l|l|l|l|}
\hline \multicolumn{4}{|c|}{ Table 1. Sample prime stimuli used in each of the four conditions. } \\
\hline Active & The 747 & radioed & the airport control tower \\
\hline Passive & The 747 & was radioed & by the airport control tower \\
\hline By-locative & The 747 & was landing & by the airport control tower \\
\hline Non-by-locative & The 747 & has landed & near the airport control tower \\
\hline
\end{tabular}

\footnotetext{
${ }^{3}$ On average, our Non-by-locative prepositions were less frequent than by $(1,293,156$ vs. 2,068,768; values from the Corpus of Contemporary American English [COCA], Davies, 2008; see Appendix C), V=20, $p=.02$ (two-tailed, onesample Wilcoxon signed-rank test, for non-normal data). The relative infrequency of these other prepositions can be expected to increase their surprisal, which in turn predicts stronger priming effects for Non-by-locatives than $B y$ locatives (e.g., Jaeger \& Snider, 2013). Thus, if we find no priming in Non-by-locatives, it cannot be explained by these differences in frequency. We also considered how likely each preposition was given the verb (conditional probability). These values did not differ between the By-locatives and Non-by-locatives (.04 vs. .06; values calculated from COCA; see Appendix C), $V=250, p=.80$ (two-tailed, paired-sample Wilcoxon signed-rank test, for non-normal data). Thus, any differences we see in priming between the two conditions also cannot be attributed to differences in conditional probability.
} 
Each priming sentence was paired with one of 32 experimental pictures. The pictures were line drawings that depicted events involving two participants, typically an inanimate or non-human agent or initiator of the action (e.g., wrecking ball) and an animate or inanimate undergoer of the action (e.g., building). Sixteen of the scenarios depicted were from the original Bock and Loebell (1990) experiment. Fourteen of the experimental pictures (44\%) had the agent on the left, another fourteen (44\%) had the agent on the right, and four (12\%) were neutral as to the orientation of the agent relative to the undergoer on the horizontal plane (in all four, the agent was above the undergoer). All 32 experimental pictures were previously normed on Amazon Mechanical Turk $(\mathrm{N}=195)$ by asking participants to write descriptions for 6-10 assorted pictures using only one sentence each, yielding a $91 \%$ median use of active or passive transitive sentences (range $=36-100 \%$ ) and, among these, a $23 \%$ mean proportion of passives. (For a full list of all target pictures, see Appendix B.) Prime sentences and target pictures were randomly paired across participants. Verbs did not repeat from prime to target.

We used 42 filler sentences and 40 filler pictures. One function of these filler items was to mask the true purpose of the experiment: Participants were asked to perform a distractor memory task and indicate whether they had seen each item (sentence or picture) before or not. For this purpose, we repeated 26 of the 42 filler sentences and 28 of the 40 filler pictures, yielding a total of 68 filler sentences and 68 filler pictures. The 42 unique filler sentences instantiated a wide variety of constructions, such as clefts (e.g., It was an old lady who discovered the weapon), existentials (e.g., There is a red spot on Jupiter), resultatives (e.g., The girl laughed herself silly), datives (e.g., The singer gave the piano player a wave), generics (e.g., All humans are mammals), intransitives (e.g., The graceful young girl danced), and clausal complements (e.g., The man admitted that he was wrong). None of the filler sentences were 
passives. The 40 unique filler pictures depicted a variety of events involving one or more participants, typically described with intransitive sentences (e.g., boy shivering in cold, two bikes leaning on fence, girl running toward house, cat hiding behind chair, two skiers skiing). Care was taken to not select filler pictures that elicited transitive (active or passive) descriptions. In total, each participant saw 100 sentences (including the 32 primes) and 100 pictures (including the 32 targets). Filler trials were interspersed randomly between critical trials, with the constraint that the first five trials be fillers and at least one but not more than two filler trials intervene between critical trials.

\subsection{Procedure}

The study was administered online via Amazon Mechanical Turk using psiTurk (Gureckis et al., 2016). Participants were asked to read each sentence out loud, and to give an accurate description of each picture using the verb provided, all while recording themselves with their microphones. They were given a single opportunity to make each recording, and a microphone check preceded the task. See Fig. 2 for procedure and example materials. Participants were told to not use pronouns, to mention every depicted character, and to be as precise as possible.

For the distractor memory task, participants indicated whether they had seen each item (sentence or picture) before or not by pressing the appropriate key (left arrow for NO, right arrow for YES) on their keyboards. A post-test questionnaire confirmed that none of the participants doubted the cover story or realized the true purpose of the experiment. The whole experiment lasted approximately 45 minutes. 


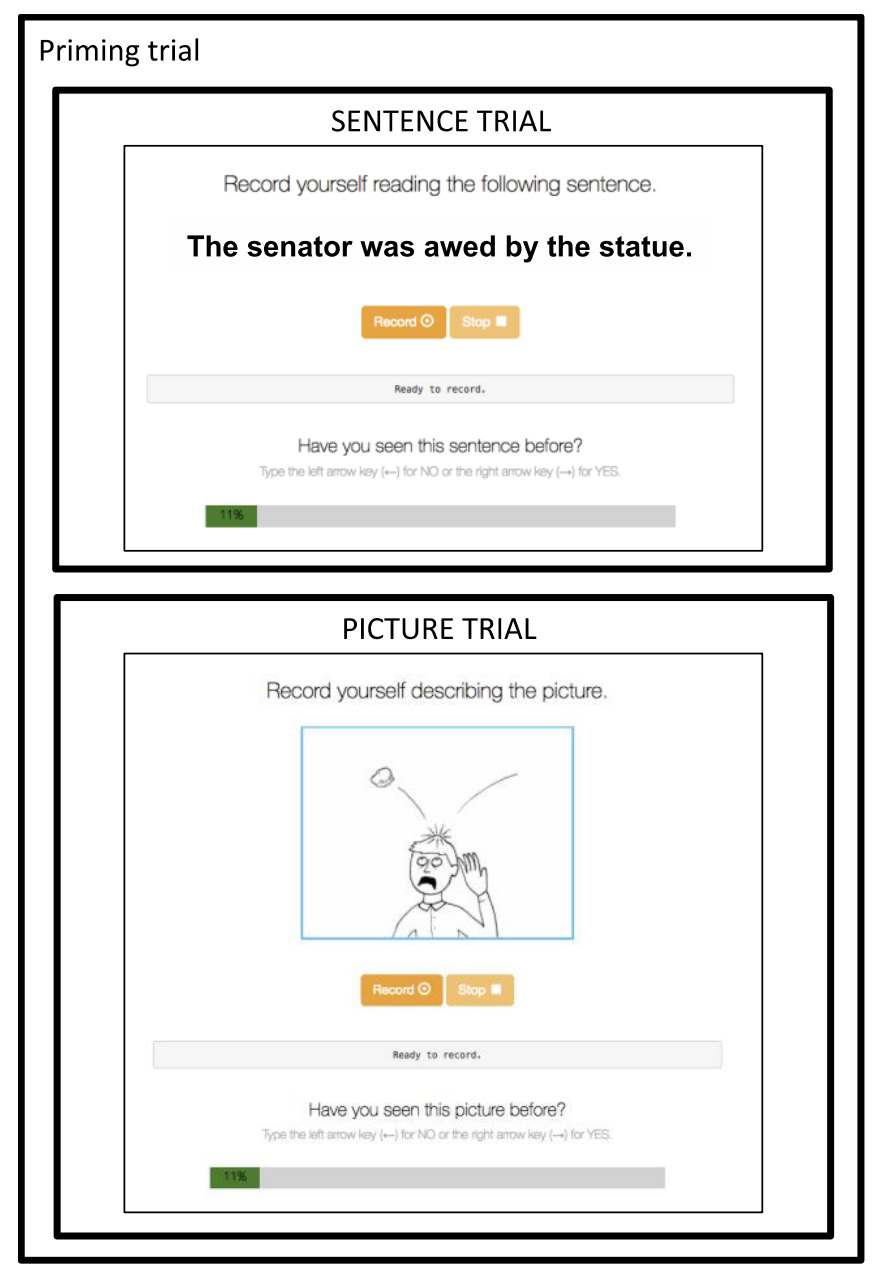

Figure 2. Procedure and example materials.

\subsection{Design}

We used a $3 \times 2$ mixed design, with Prime Condition (Passive, $B y$-locative, Non-by-locative) as a between-subjects factor and Prime Type (Non-active, Active) as a within-subjects factor. Thus, each participant saw exactly 2 conditions, 16 prime sentences of each. We manipulated Prime Condition between subjects to maximize the likelihood of observing priming in the Non-bylocative condition. This gave us $\sim 94 \%$ power to detect priming in each condition (at a Cohen's $d$ of .28 without lexical overlap; see Mahowald et al., 2016, p. 21 ), and $\sim 87 \%$ power to detect interactions between conditions (at a Cohen's $d$ of .28; see Mahowald et al., 2016, p. 21). 
Participants were randomly assigned to the three Prime Conditions and then to one of eight counterbalanced lists within each Prime Condition. The dependent measure was the number of passive sentences produced by participants (coded as 1 , with actives coded as 0 ), out of all transitive responses (passive/active+passive). In presenting the production cell means (for descriptive purposes), we have aggregated over both participants and items.

\subsection{Coding}

The descriptions of the experimental pictures were scored for syntactic structure. If the description consisted of more than one sentence, only the first complete sentence containing both the agent and the undergoer was scored. If participants hesitated, stuttered, or produced a false start, the final form of the utterance was scored. Responses were divided into one of the three categories: Active, By-Passive, and Other.

To be scored as an Active, a target description had to provide an appropriate description of the transitive event in the target picture; had to contain the agent or initiator of the event in subject position, a verb in the active voice, and the undergoer of the event in object position; and had to be expressible in the alternative form (i.e., as a passive). To be scored as a By-Passive, a description had to be a complete sentence that appropriately described the target picture's event; had to contain the undergoer role in subject position, an auxiliary verb (be or get), a main transitive verb, and a prepositional by-phrase with an agentive object; and had to be expressible in the alternative form (i.e., as an active). Transitive sentences with prepositional particles (e.g., crash into) were included in the analysis, so long as they could occur in both the active and the passive form. All other descriptions (including truncated, lexical, or instrumental passives; datives; intransitives; and incomplete, inaudible, or unintelligible utterances) were scored as 
Other. In total, 7,473 of the 8,770 produced target descriptions $(85.2 \%)$ were transitive responses (i.e., Active or By-Passive) and thus entered into the analysis. Ten percent of the target responses were independently coded by a second coder, with an intercoder reliability of $99 \%$ (Cohen's $\kappa=.98)$.

\subsection{Data analysis}

We analyzed the data with a logistic mixed-effects model (Baayen, Davidson, \& Bates, 2008; Jaeger, 2008) in the lme4 package in R (Bates, 2010), with Prime Condition (Passive, Bylocative, Non-by-locative), Prime Type (Non-active, Active), and their interaction as fixed effects. We started with the maximal random effects structure appropriate for our experimental design (Barr, Levy, Scheepers, \& Tily, 2013). However, this model failed to converge. The final model included random intercepts for participant and item (target picture), a random slope for Prime Type within participants, and a random slope for Prime Condition within items. All fixed effects were effect coded $(1,-1)$. We performed forward model comparisons using likelihoodratio tests (anova function in $\mathrm{R}$ ) to determine the significance of our fixed effects. Table 2 summarizes the results of these comparisons. Planned pairwise analyses were run on the full model minus the relevant level of Prime Condition.

In addition, we calculated Bayes factors for the effect of priming in each condition. Unlike $p$-values, which only provide evidence for how unexpected the data are under the null hypothesis, Bayes factors allow us to compare the likelihood of the data fitting under the null hypothesis with the likelihood of the data fitting under the alternative hypothesis. The higher a Bayes factor $\left(B F_{01}\right)$, the more evidence in support of the null hypothesis; the inverse of this value thus tells us how likely the data are to occur under the alternative hypothesis $\left(B F_{10}\right)$. We 
calculated our Bayes factors using Bayesian Information Criteria (BIC; Jarosz \& Wiley, 2014; Wagenmakers, 2007). We first extracted the BIC for each hypothesis by fitting and comparing two separate regression models: one that characterizes the alternative hypothesis $\left(\mathrm{H}_{1}\right.$ : including an effect for Prime Type, plus random intercepts for both participant and item) and one that characterizes the null hypothesis $\left(\mathrm{H}_{0}\right.$ : same model without the effect for Prime Type). We then found the difference of these values:

$$
\Delta \mathrm{BIC}_{10}=\mathrm{BIC}_{\mathrm{H}_{1}}-\mathrm{BIC}_{\mathrm{H}_{0}}
$$

Finally, we transformed this into a Bayes factor:

$$
B F_{01}=e^{\Delta \mathrm{BIC}_{10} / 2}
$$

And we took the inverse to quantify the odds in favor of $\mathrm{H}_{1}$ :

$$
B F_{10}=1 / B F_{01}
$$

\begin{tabular}{|c|c|c|c|c|}
\hline Fixed effect term & $\mathrm{AIC}(\triangle \mathrm{AIC})$ & $\mathrm{df}(\Delta \mathrm{df})$ & $\chi^{2}$ & $p=$ \\
\hline $\begin{array}{l}\text { Base model: Random intercepts for } \\
\text { participant and item + random slope for } \\
\text { Prime Type within participants + random } \\
\text { slope for Prime Condition within items }\end{array}$ & $5522.7(---)$ & $10(---)$ & --- & --- \\
\hline + Prime Type $(\mathrm{PT})$ & $5479.4(-43.3)$ & $11(1)$ & 45.28 & $<.001 *$ \\
\hline+ Prime Condition $(\mathrm{PC})$ & $5466.6(-12.8)$ & $13(2)$ & 16.82 & $<.001 *$ \\
\hline
\end{tabular}

Table 2. Stepwise forward model comparisons for fixed effects. 


\begin{tabular}{|l|l|l|l|l|}
\hline$+\mathrm{PT} \times \mathrm{PC}$ & $5459.2(-7.4)$ & $15(2)$ & 11.41 & .003 \\
\hline
\end{tabular}

*Significant at the $p<.05$ level.

\section{Results}

Accuracy on the distractor memory task was high (94\%), with no differences by Prime

Condition. Fig. 3 shows the pattern of priming results. The model comparisons revealed a significant main effect of Prime Type, such that passives were produced significantly more often after Non-active (Passive, By-locative, Non-by-locative) primes than after Active primes (26.0\% vs. $22.0 \%$ ), independent of condition, $\chi^{2}(1)=45.28, p<.001$. However, this was in the context of a significant Prime Type by Prime Condition interaction, $\chi^{2}(2)=11.41, p=.003$. Planned pairwise comparisons revealed that priming for Passives was significantly greater than that for Non-bylocatives $(7.1 \%$ vs. $-0.8 \%), \beta=.16(\mathrm{SE}=.04), z=3.51, p<.001$, but did not significantly differ from that for $B y$-locatives (7.1\% vs. 5.9\%), $\beta=.04(\mathrm{SE}=.05), z=.89, p=.38$, and that priming for $B y$ locatives was significantly greater than that for Non-by-locatives (5.9\% vs. $-0.8 \%)$, $\beta=.11(\mathrm{SE}=.05), z=2.35, p=.02$. There was also a significant main effect of Prime Condition, $\chi^{2}(2)=16.82, p<.001$. The planned pairwise comparisons revealed that significantly more passives were produced in the Passive condition as compared to either the $B y$-locative condition (27.2\% vs. $24.4 \%), \beta=.17(\mathrm{SE}=.09), z=2.00, p=.046$, or the Non- $b y$-locative condition $(27.2 \%$ vs. $20.4 \%)$, $\beta=.36(\mathrm{SE}=.11), z=3.24, p=.001$, but the proportion of overall passive responses in the $B y$-locative condition was not significantly different from that in the Non-by-locative condition $(24.4 \%$ vs. $20.4 \%), \beta=.19(\mathrm{SE}=.12), z=1.64, p=.10 .^{4}$

\footnotetext{
${ }^{4}$ We wanted to see whether this held for the Active primes as well as the Non-active primes. In a post-hoc analysis, we ran the same pairwise comparisons on the Active primes only (without Prime Type in the model): Although
} 
Our Bayes factor analysis suggested that the data in the Passive condition were $>150$ times more likely to occur under a model including Prime Type (=priming) than a model without it (=no priming). The data in the $B y$-locative condition were $>150$ times more likely to occur under a model including Prime Type (=priming) than a model without it (=no priming). Lastly, the data in the Non-by-locative condition were .02 times more likely to occur under a model including Prime Type (=priming) than a model without it (=no priming), or in others words, 44 times more likely to occur under a model without Prime Type (=no priming) than a model with it (=priming). Thus, by standard analysis (e.g., Jeffreys, 1961; Raftery, 1995), there is very strong or decisive evidence in support of priming in both the Passive and By-locative conditions, and conversely, strong or very strong evidence against priming in the Non-by-locative condition.

significantly more passives were produced following Active primes in the Passive condition as compared to the Non- $b y$-locative condition $(23.7 \%$ vs. $20.8 \%), \beta=.26(\mathrm{SE}=.13), z=2.06, p=.04$, the proportion of overall passive responses following Active primes in the By-locative condition was not significantly different from that in either the Passive condition $(21.4 \%$ vs. $23.7 \%), \beta=.18(\mathrm{SE}=.12), z=1.45, p=.15$, or the Non-by-locative condition $(21.4 \%$ vs. $20.8 \%), \beta=.12(\mathrm{SE}=.14), z=.87, p=.39$. 

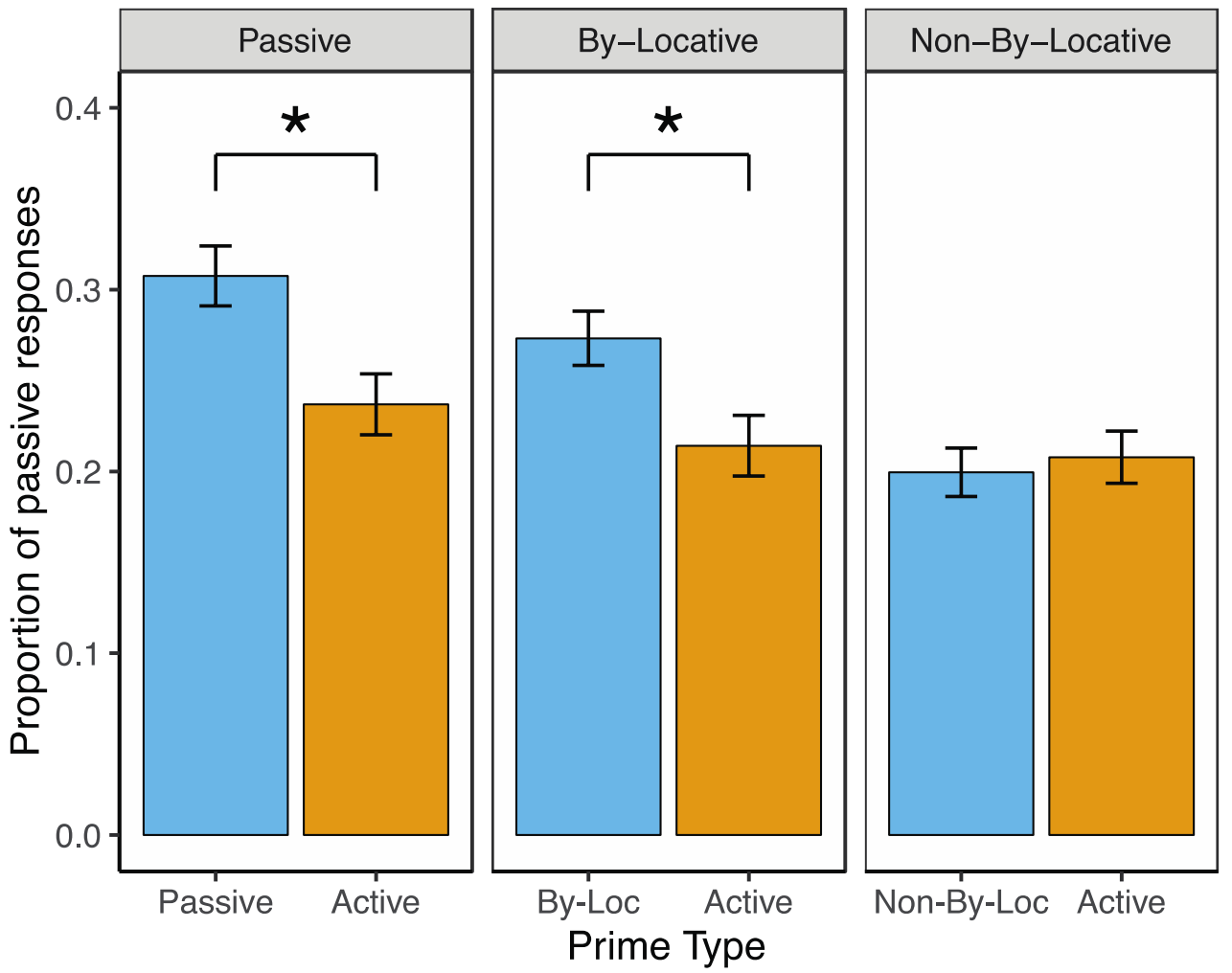

Figure 3. Overall proportion of passive productions by Prime Type by Prime Condition. Error bars reflect by-subject standard errors. By-Loc $=B y$-locative; Non-By-Loc=Non- $b y$-locative.

\section{Discussion}

We revisited a key finding in the structural priming literature that has been widely used to argue for bare constituent tree priming: that intransitive locative sentences prime passives (e.g., Bock \& Loebell, 1990). We asked whether this effect was in fact due to a tendency to repeat fully abstract syntactic phrase structures, or if it might instead reflect the priming of something less abstract: an adjunct by-phrase. We have three clear findings. First, like in much past work, we replicated priming from passives to other passives, relative to active controls (see Mahowald et al., 2016). Second, we replicated Bock and Loebell's (1990) finding of (equivalent) passive priming from $b y$-locatives. Third and critically, however, we failed to find any evidence of 
priming from non-by-locatives to passives. Our Bayes factor analysis confirmed these interpretations. Together, these data provide strong evidence that the priming of passives by bylocatives is due, at least in part, to the presence of shared lexical content (by, be), and not to an abstract, content-less phrase structure.

Notably, we also replicated Bock and Loebell's (1990) finding that semantic roles do not contribute to passive priming. That is, we found no evidence that the magnitude of priming from passives to passives was greater than that from by-locatives to passives. Instead, priming in this task appears to be driven solely by the presence of the by-phrase, regardless of its semantic interpretation (agent vs. location) or the constituent structure of the clause.

One possible interpretation of the results is that the by-phrases in the prime sentences activate stored pieces of lexically-specified syntax, rather than an abstract prepositional phrase schema that can have any preposition slotted into it. This level of description is consistent with linguistic traditions that reject a strict division between syntax and the lexicon and allow for (and in fact predict) the existence of intermediate generalizations: linguistic entities that combine abstract schematic knowledge with more concrete and lexically-specified knowledge (e.g., Croft, 2001; Fillmore, 1985; Goldberg 1995, 2006; Jackendoff, 2002, 2007; Langacker, 1987;

O’Donnell, 2015; Oehrle, Bach, \& Wheeler, 2012; Pollard \& Sag, 1994; Schabes, Abeillé, \& Joshi, 1988). It is alternatively possible that what's doing all the work is the lexical item by on its own, rather than the full prepositional phrase which it heads. ${ }^{5}$ One reason why we might favor the stored structure account is that prior data, using different constructions, found no evidence for the priming of function words independent of their interpretation (Bock \& Loebell, 1990, Exp. 3; Ferreira, 2003). For example, Ferreira (2003) found a greater increase in that-

\footnotetext{
${ }^{5}$ One fact that makes this a distinct possibility is that by contains a diphthong vowel, making it bimoraic: [bai]. Thus, it is a strong (and memorable) syllable.
} 
complementization (e.g., The mechanic mentioned that the car could use a tune-up) following other that-complementization structures (e.g., The company insured that the farm was covered for two million dollars) than following a complementization structure without that (e.g., The company insured __ the farm was covered for two million dollars). Critically, there was no increase in that-complementization following transitive sentences with the functionally distinct deictic that (e.g., The company insured that farm for two million dollars). Likewise, Bock and Loebell (1990, Exp. 3) found no influence of infinitive to (e.g., Susan brought a book to study) on to-dative productions (e.g., The girl is handing a paintbrush to the boy). If the same processes are at work in complement priming, dative priming, and passive priming, then we should not expect by on its own to prime passives. At the same time, there are good reasons to believe that priming varies systematically across constructions depending on the representational basis of the alternation (see Ziegler, 2019; Ziegler et al., 2018). For this reason, we are reluctant to draw strong conclusions from these prior findings. Thus, it remains to be seen whether this priming is due to the by-phrase or by on its own.

In sum, the central message of the present findings is that passive priming does not result from the repetition of abstract constituent structure alone (cf. Bock \& Loebell, 1990; Branigan \& Pickering, 2017). In the remainder of this discussion, we situate our results in the context of the wider structural priming literature. We first discuss our assumptions about syntax (section 4.1). We then review the evidence that has been offered in favor of content-less tree priming to determine whether it can be integrated with the present findings (section 4.2).

\subsection{A note on passive syntax}


While the simplified syntactic structure in Fig. $1 \mathrm{~b}$ led to the prediction that intransitive locatives should prime passives, in reality, there is little agreement about passive syntax. More elaborate syntactic structures have been proposed in order to represent unexpressed aspects of semantics and discourse structure. For example, an influential proposal by Baker, Johnson, and Roberts (1989) treats passive sentences as underlyingly transitive (see Fig. 4). This proposal captures the idea that the subject argument of a passive corresponds to the direct object argument of an active sentence. On this theory, the distinct discourse function of the passive construction is represented by the inclusion of a passive morpheme "argument," represented in Fig. 4 by -en, and the lack of a causer argument.

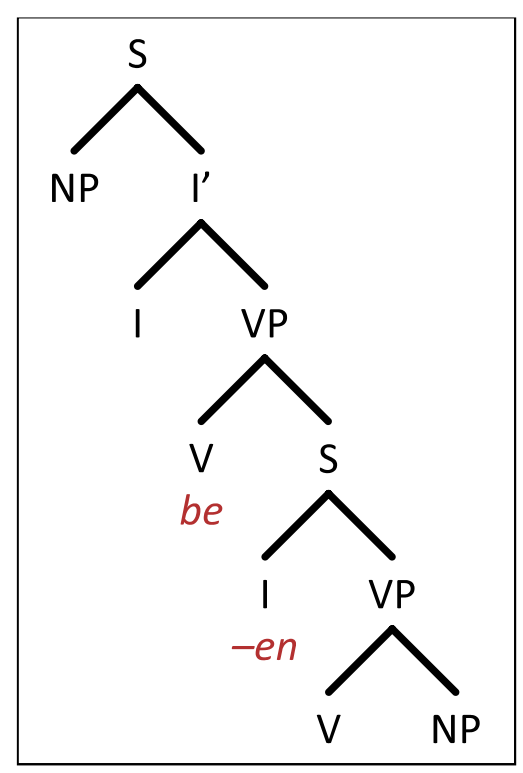

Figure 4. Schematic (underlyingly) transitive representation of the passive proposed by Baker, Johnson, and Roberts (1989).

Other frameworks have treated the passive as a construction (e.g., Culicover \& Jackendoff, 2005; Ginzburg \& Sag, 2001) or as surface projections of individual verbs (e.g., 
Bresnan, 1982; Pollard \& Sag, 1987). These proposals consider the passive to be syntactically intransitive, with semantics and discourse structure represented by other means. Researchers have also debated whether the $b y$-phrase should be treated as an adjunct (e.g., Legate, 2014), an argument (e.g., Koenig, Mauner, \& Bienvenue, 2003), or something in between (e.g., Grimshaw, 1990).

But importantly, no one has proposed distinct abstract tree configurations for sentences solely on the basis of the inclusion of distinct locative prepositions such as by vs. near. In order for the current set of results to be explained by syntactic priming, this assumption would be needed. Thus, the main conclusion we draw remains valid: The fact that intransitive $b y$-locatives prime passives does not provide evidence in support of abstract syntactic priming.

\subsection{Is there unambiguous evidence for the priming of abstract, content-less syntactic trees?}

In addition to Bock and Loebell (1990), there are several other findings which have been argued to demonstrate that content-less phrase structure can be primed. The challenge in every case is to isolate this level of representation, given that most of the alternations we study will also vary in their lexical content, semantic event structure, information structure, and/or syntax-animacy mappings. Here we explore whether there is any priming result that must be attributed to the priming of phrase structure, with no potential confounds. We first review priming in passives, and then we branch out to other constructions.

As we can see in Table 3, the vast majority of passive priming studies are confounded by lexical content (rows 1-3), as was the case in Bock and Loebell (1990, Exp. 2). However, there are two kinds of studies where this is not the case. The first is cross-linguistic studies, in which bilingual participants are primed in one language and asked to generate target descriptions in 
another language (Chen, Jia, Wang, Dunlap, \& Shin, 2013; Hartsuiker, Pickering, \& Veltkamp, 2004; rows 4 and 5). Since the morphemes used to mark passives are distinct in the two languages, these studies appear to rule out lexicalized representations as the locus of priming. The second is a study by Messenger et al. (2011), in which participants were primed by short passives that did not contain an agentive by-phrase (e.g., The girls are being shocked) and produced full passives with the by-phrase (e.g., The king is being scratched by the tiger; row 6). While none of these studies allows for lexical priming (though see fn. 9), they all have at least one potential locus of priming other than content-less phrase structure (see Table 3): information structure, or the way information is "packaged" within a sentence (e.g., Lambrecht, 1994). Some evidence for information structural priming comes from Vernice, Pickering, and Hartsuiker (2012), who found a tendency for Dutch-speaking participants to produce more passive sentences (e.g., De jongen wordt geraakt door de bal "The boy is hit by the ball"), which make the undergoer argument the sentence topic, following a cleft sentence with a topicalized undergoer (e.g., Degene die hij slaat is de cowboy "The one who he is hitting is the cowboy") than one with a topicalized agent (e.g., Degene die hem slaat is de cowboy "The one who is hitting him is the cowboy”), despite differences in surface syntax (for other evidence, see, e.g., Bernolet, Hartsuiker, \& Pickering, 2009; Fleischer, Pickering, \& McLean, 2012; Heydel \& Murray, 2000; Ziegler \& Snedeker, 2019). ${ }^{6}$ Thus, none of the passive priming studies provide

\footnotetext{
${ }^{6}$ Bernolet et al. (2009) examined the priming of English passives by variants of the Dutch passive: namely, Dutch passives with the by-phrase positioned sentence-initially, -medially, or -finally. Results demonstrated that the medial and final cases serve a function analogous to the English passive in emphasizing the patient argument (see also Cornelis, 1996), and they both primed English passives. However, statistically stronger priming was found for the variant that shared with English both information structure and constituent structure (passives with sentence-final by-phrase) over just information structure alone. At face value, this might suggest a role for the contribution of abstract syntax to priming. However, this pattern could also be due to a deeper difference in information structure between the two variants (which likely "differ in the emphasis given to the agent [...] because it takes a different sentence position"; Bernolet et al., 2009, p. 302) or, as we suggest for other cases below, differences in prosody.
} 
unambiguous evidence for the priming of abstract syntax (vs. lexicalized syntax, lexical content on its own, information structure, or some combination thereof).

\begin{tabular}{|c|c|c|c|c|c|}
\hline Study & $\begin{array}{l}\text { Prime } \\
\text { structure }\end{array}$ & $\begin{array}{l}\text { Target } \\
\text { structure }\end{array}$ & $\begin{array}{l}\text { Shared } \\
\text { phrase } \\
\text { structure? }\end{array}$ & $\begin{array}{l}\text { Shared } \\
\text { lexical } \\
\text { item? }\end{array}$ & $\begin{array}{l}\text { Shared } \\
\text { information } \\
\text { structure? }\end{array}$ \\
\hline $\begin{array}{l}\text { Bock \& Loebell } \\
\text { (1990, Exp. 2); } \\
\text { many others (for } \\
\text { references, see } \\
\text { Mahowald et al., } \\
\text { 2016) }\end{array}$ & $\begin{array}{l}\text { The } 747 \text { was } \\
\text { alerted by the } \\
\text { airport's control } \\
\text { tower }\end{array}$ & $\begin{array}{l}\text { A golfer } \\
\text { was struck } \\
\text { by lightning }\end{array}$ & $\checkmark$ & $\checkmark$ (by) & $\checkmark$ \\
\hline $\begin{array}{l}\text { Bock \& Loebell } \\
(1990, \text { Exp. } 2)\end{array}$ & $\begin{array}{l}\text { The } 747 \text { was } \\
\text { landing by the } \\
\text { airport's control } \\
\text { tower }\end{array}$ & $\begin{array}{l}\text { A golfer } \\
\text { was struck } \\
\text { by lightning }\end{array}$ & $\checkmark$ & $\checkmark$ (by) & $x$ \\
\hline $\begin{array}{l}\text { Messenger et al. } \\
\text { (2012) }\end{array}$ & $\begin{array}{l}\text { A girl is being } \\
\text { shocked by a } \\
\text { sheep }\end{array}$ & $\begin{array}{l}\text { A king is } \\
\text { being } \\
\text { scratched } \\
\text { by a tiger }\end{array}$ & $\checkmark$ & $\checkmark$ (by) & $\checkmark$ \\
\hline
\end{tabular}




\begin{tabular}{|c|c|c|c|c|c|}
\hline $\begin{array}{l}\text { Hartsuiker et al. } \\
\text { (2004) }\end{array}$ & $\begin{array}{l}\text { El camión es } \\
\text { perseguido por } \\
\text { el taxi "The } \\
\text { truck is chased } \\
\text { by the taxi" }\end{array}$ & $\begin{array}{l}\text { A bottle is } \\
\text { hit by a } \\
\text { bullet }\end{array}$ & $\checkmark$ & X & $\checkmark$ \\
\hline Chen et al. (2013) & $\begin{array}{l}\text { 杯子被小猫打 } \\
\text { 破了“cup by } \\
\text { cat broken” }\end{array}$ & $\begin{array}{l}\text { Boxes were } \\
\text { knocked } \\
\text { over by a } \\
\text { ball }\end{array}$ & $x$ & $x$ & $\sqrt{ }$ \\
\hline $\begin{array}{l}\text { Messenger et al. } \\
\text { (2011) }\end{array}$ & $\begin{array}{l}\text { The girls are } \\
\text { being shocked }\end{array}$ & $\begin{array}{l}\text { A king is } \\
\text { being } \\
\text { scratched } \\
\text { by a tiger }\end{array}$ & $\begin{array}{l}\checkmark \text { (partial, } \\
\text { unless } \\
\text { covert) }\end{array}$ & $\begin{array}{l}X \\
\text { (unless } \\
\text { covert) }\end{array}$ & $\checkmark$ \\
\hline
\end{tabular}

As mentioned previously, there is reason to think that priming varies by construction depending on the representations involved (see, e.g., Ziegler, 2019; Ziegler et al., 2018). Thus, evidence that abstract, content-less trees can be primed in some cases would not provide evidence that they can be primed in all cases. Above, we reviewed passive priming and found no unambiguous evidence for the influence of abstract, content-less phrase structure. We next consider candidate evidence for abstract tree structure priming in other constructions, summarized in Table $4 .^{7}$

\footnotetext{
${ }^{7}$ Another common case that has been used to argue for abstract syntax is the priming of attachment ambiguities (e.g., Desmet \& Declercq, 2006; Scheepers, 2003). However, this type of priming is always confounded with differences in semantic event structure (which we know to be primable; see introduction). We therefore do not discuss it further.
} 
Several of these studies (rows 1-4) build on another experiment in Bock and Loebell (1990, Exp. 1) in which motion verb sentences with locative prepositional phrases (e.g., The wealthy widow drove an old Mercedes to the church) were shown to prime to-datives (e.g., The girl is handing a paintbrush to the boy; row 1). While all of the motion verb primes and dative targets contained the preposition to in the original experiment, leaving open a lexical explanation (see also Potter \& Lombardi, 1998), subsequent studies eliminated the preposition as the locus of priming (Fox Tree \& Meijer, 1999, Exp. 1; Salamoura \& Williams, 2007, Exp. 3; Ziegler \& Snedeker, 2018, Exp. 11; rows 2-4). Nevertheless, these studies all had a common feature which suggests another possible locus of priming. Specifically, in each case, the alternative prime against which the motion verb sentences were compared was the double-object dative (e.g., Sue gave the dog a bone). Double-object datives differ from both motion verbs and to-datives in their information structure, semantic event structure, and syntax-animacy mappings. Thus, priming at any of these levels of representation could have resulted in the observed difference between the prime conditions (i.e., double-object dative primes may be pulling to-dative production down, rather than to-dative primes pulling it up).

Several other findings that manipulated the order of information in the sentence are summarized in rows 5-7. Hartsuiker et al. (1999) found that scrambled Dutch sentences in which the subject followed the verb led to more productions in which the subject followed the verb than did canonical subject-first orderings (row 5). But this type of word order difference is known to predict differences in information structure in Germanic and other languages (Hinterhölzl \& Petrova, 2009; Lambrecht, 1994). Cleland and Pickering (2003) showed that relative-clause modification in English led to more relative clause productions than did prenominal attributive modification (row 6; see also Bernolet, Hartsuiker, \& Pickering, 2007), but there is evidence that 
predicative modification (by a relative clause) differs from attributive modification, both semantically and in terms of information structure (e.g., Bolinger, 1967). Bernolet, Hartsuiker, and Pickering (2013) found priming between of-genitives in Dutch and $o f$-genitives in English, relative to the Dutch equivalent of $s$-genitives (row 7), and yet here, too, there are likely information structural and semantic differences since such differences exist between the analogous constructions in English (e.g., Stefanowitsch, 2003). Thus, none of these cases provides unambiguous evidence for pure tree priming.

There are two final results that are not easily attributed to lexical or information structural differences. Konopka and Bock (2009; see also Gries, 2005) have found priming of verb-particle placement in English: Participants produced more verb-particle constructions with the direct object intervening (e.g., The high prices scared the customers off) following configurations with the same ordering (e.g., The burglars broke the door down) than configurations in which the particle occurred right after the verb and before the direct object (e.g., The burglars broke down the door; row 8). The ordering of the particle and direct object is conditioned by various semantic and information structural factors (Gries, 1999), but the priming effect was found even when these factors were controlled for (Konopka \& Bock, 2009) or taken into account (Gries, 2005).

Another intriguing finding comes from Hartsuiker and Westenberg (2000), who found priming of auxiliary placement in Dutch: Participants were more likely to place the finite auxiliary verb in a subordinate clause before the participle (e.g., had gebroken) following a prime with the same order (e.g., was geblokkeerd) than after a prime with verb-final ordering (e.g., geblokkeerd was; row 9), regardless of whether responses were verbal or written. While differences in constituent ordering commonly reflect differences in information structure, as 
noted above, information structure does not appear to condition this difference (for discussion, see Hartsuiker \& Westenberg, 2000; Pappert \& Pechmann, 2014). Instead, the variation is conditioned by dialect, choice of auxiliary, and prosody (rhythm; De Sutter, 2009; Swerts \& van Wijk 2005). Intriguingly, the ordering of direct object and verb-particle-which also shows somewhat mysterious priming effects — has rhythmic correlates as well (Dehé, 2002). The possibility of rhythmic priming in language has not been widely studied, and the evidence that does exist is mixed: While no evidence has been found for priming of pauses within sentences (Tooley, Konopka, \& Watson, 2014, 2018), and one study found no evidence of lexical stress priming (Bock \& Loebell, 1990, Exp. 3), other work that used tone sequences found rhythmic priming for word lists (Cason \& Schön, 2012) and for sentences with matching rhythmic structure (Cason, Astésano, \& Schön, 2015). Clearly, more work is needed to determine whether (explicit or implicit) rhythmic structure, or any of the other factors besides syntax in Table 4, is responsible for the priming in each case.

\begin{tabular}{|l|l|l|l|l|l|l|}
\hline \multicolumn{5}{|c|}{ Table 4. Review of possible contributors to priming in other constructions. } \\
\hline Study & Prime & Target & Shared & Shared & Shared & Shared \\
structure & structure & phrase & lexical & information & semantics? \\
Loebell & widow drove & handing a & structure? & item? & structure? & \\
(1990, Exp. & an old & paintbrush & & $\checkmark$ (to) & $\checkmark$ (of & $\checkmark$ (of \\
1); also & Mercedes to & to the boy & & & alternative & alternative \\
Potter \& & the church & & & & double- & double- \\
\end{tabular}




\begin{tabular}{|c|c|c|c|c|c|c|}
\hline $\begin{array}{l}\text { Lombardi } \\
\text { (1998) }\end{array}$ & & & & & & \\
\hline $\begin{array}{l}\text { Ziegler \& } \\
\text { Snedeker } \\
\text { (2018, Exp. } \\
\text { 11) }\end{array}$ & $\begin{array}{l}\text { The girl } \\
\text { dragged the } \\
\text { bucket } \\
\text { around the } \\
\text { doctor }\end{array}$ & $\begin{array}{l}\text { The boy } \\
\text { brought the } \\
\text { keys to the } \\
\text { camel }\end{array}$ & $\checkmark$ & $x$ & $\begin{array}{l}\checkmark \text { (of } \\
\text { alternative } \\
\text { double- } \\
\text { object } \\
\text { structure) }\end{array}$ & $\begin{array}{l}\sqrt{ } \text { (of } \\
\text { alternative } \\
\text { double- } \\
\text { object } \\
\text { structure) }\end{array}$ \\
\hline $\begin{array}{l}\text { Fox Tree \& } \\
\text { Meijer } \\
\text { (1999, Exp. } \\
\text { 1) }\end{array}$ & $\begin{array}{l}\text { The } \\
\text { musician } \\
\text { needs to } \\
\text { borrow a } \\
\text { microphone } \\
\text { from his } \\
\text { friend } \\
\text { tonight }\end{array}$ & $\begin{array}{l}\text { While the } \\
\text { poet } \\
\text { traveled in } \\
\text { France, she } \\
\text { wrote many } \\
\text { letters to } \\
\text { her family }\end{array}$ & $\checkmark$ & $x$ & $\begin{array}{l}\checkmark \text { (of } \\
\text { alternative } \\
\text { double- } \\
\text { object } \\
\text { structure) }\end{array}$ & $\begin{array}{l}\checkmark \text { (of } \\
\text { alternative } \\
\text { double- } \\
\text { object } \\
\text { structure) }\end{array}$ \\
\hline $\begin{array}{l}\text { Salamoura } \\
\text { \& Williams } \\
\text { (2007, Exp. } \\
\text { 3) }\end{array}$ & 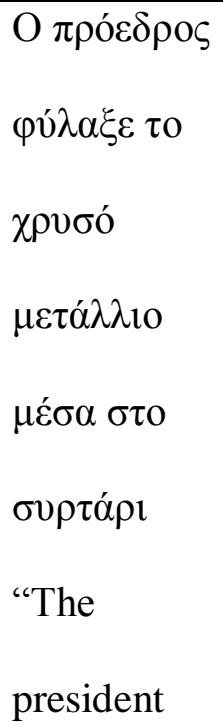 & $\begin{array}{l}\text { The hotel } \\
\text { receptionist } \\
\text { gave [a key } \\
\text { to the } \\
\text { guest] }\end{array}$ & $\checkmark$ & $x$ & $\begin{array}{l}\checkmark \text { (of } \\
\text { alternative } \\
\text { double- } \\
\text { object } \\
\text { structure) }\end{array}$ & $\begin{array}{l}\checkmark \text { (of } \\
\text { alternative } \\
\text { double- } \\
\text { object } \\
\text { structure) }\end{array}$ \\
\hline
\end{tabular}




\begin{tabular}{|c|c|c|c|c|c|c|}
\hline & $\begin{array}{l}\text { kept the gold } \\
\text { medal in the } \\
\text { drawer" }\end{array}$ & & & & & \\
\hline $\begin{array}{l}\text { Hartsuiker } \\
\text { et al. (1999) }\end{array}$ & $\begin{array}{l}\text { Op de tafel } \\
\text { ligt een bal } \\
\text { "On the } \\
\text { table lies a } \\
\text { ball" (vs. } \\
\text { Een bal ligt } \\
\text { op de tafel } \\
\text { "A ball lies } \\
\text { on the } \\
\text { table") }\end{array}$ & $\begin{array}{l}\text { Naast het } \\
\text { hok zit een } \\
\text { hond } \\
\text { "Beside the } \\
\text { kennel sits } \\
\text { a dog" }\end{array}$ & $\checkmark$ & $x$ & $\checkmark$ & $x$ \\
\hline $\begin{array}{l}\text { Cleland \& } \\
\text { Pickering } \\
\text { (2003); also } \\
\text { Bernolet et } \\
\text { al. }(2007)^{8}\end{array}$ & $\begin{array}{l}\text { The square } \\
\text { that's red } \\
\text { (vs. The red } \\
\text { square) }\end{array}$ & $\begin{array}{l}\text { The square } \\
\text { that's green } \\
\text { / The } \\
\text { diamond } \\
\text { that's red }\end{array}$ & $\checkmark$ & $\begin{array}{l}\checkmark \\
\text { (that) }\end{array}$ & $\checkmark$ & $\checkmark$ \\
\hline
\end{tabular}

\footnotetext{
${ }^{8}$ Bernolet et al. (2007) found differential priming for attributive vs. predicative constructions within English, within Dutch, and between Dutch and German, but not between Dutch and English. We know that translation-equivalents boost priming (Bernolet, Hartsuiker, \& Pickering, 2012; Cai, Pickering, Yan, \& Branigan, 2011; Schoonbaert, Hartsuiker, \& Pickering, 2007), which would predict equivalent priming between Dutch and English as between Dutch and German. However, Bernolet et al. (2012) have found that priming across languages increases with phonological overlap in the syntactic head (in this case, the relativizer that/dielder). The greater phonological similarity between die and der could predict greater priming between Dutch and German than between Dutch and English. Therefore, consistent with the current findings, partially lexicalized translation equivalents ( $\operatorname{Re}_{\text {dielder }} \operatorname{Adj} \mathrm{V}$ ) may result in more priming than translation equivalents with less analogous morphosyntax $\left(\operatorname{Rel}_{\text {that }} \mathrm{V}\right.$ Adj).
} 


\begin{tabular}{|c|c|c|c|c|c|c|}
\hline $\begin{array}{l}\text { Bernolet et } \\
\text { al. (2013) }\end{array}$ & $\begin{array}{l}\text { Het hemd } \\
\text { van de } \\
\text { jongen "The } \\
\text { shirt of the } \\
\text { boy" (vs. De } \\
\text { jongen zijn } \\
\text { hemd "The } \\
\text { boy his } \\
\text { [=boy's] } \\
\text { shirt") }\end{array}$ & $\begin{array}{l}\text { The egg of } \\
\text { the nurse }\end{array}$ & $\checkmark$ & $x$ & $\checkmark$ & $\checkmark$ \\
\hline $\begin{array}{l}\text { Konopka \& } \\
\text { Bock } \\
\text { (2009); also } \\
\text { Gries } \\
\text { (2005) }\end{array}$ & $\begin{array}{l}\text { The burglars } \\
\text { broke the } \\
\text { door down } \\
\text { (vs. The } \\
\text { burglars } \\
\text { broke down } \\
\text { the door) }\end{array}$ & $\begin{array}{l}\text { The high } \\
\text { prices } \\
\text { scared the } \\
\text { customers } \\
\text { off }\end{array}$ & $\checkmark$ & $x$ & $\checkmark(?)$ & $x$ \\
\hline $\begin{array}{l}\text { Hartsuiker } \\
\& \\
\text { Westenberg } \\
(2000)\end{array}$ & $\begin{array}{l}\text {...omdat de } \\
\text { weg } \\
\text { geblokkeerd } \\
\text { was } \\
\text { "because the } \\
\text { road blocked }\end{array}$ & $\begin{array}{l}\text {...omdat hij } \\
\text { zijn been } \\
\text { gebroken } \\
\text { had } \\
\text { "because he } \\
\text { his leg }\end{array}$ & $\checkmark$ & $x$ & $x$ & $x$ \\
\hline
\end{tabular}




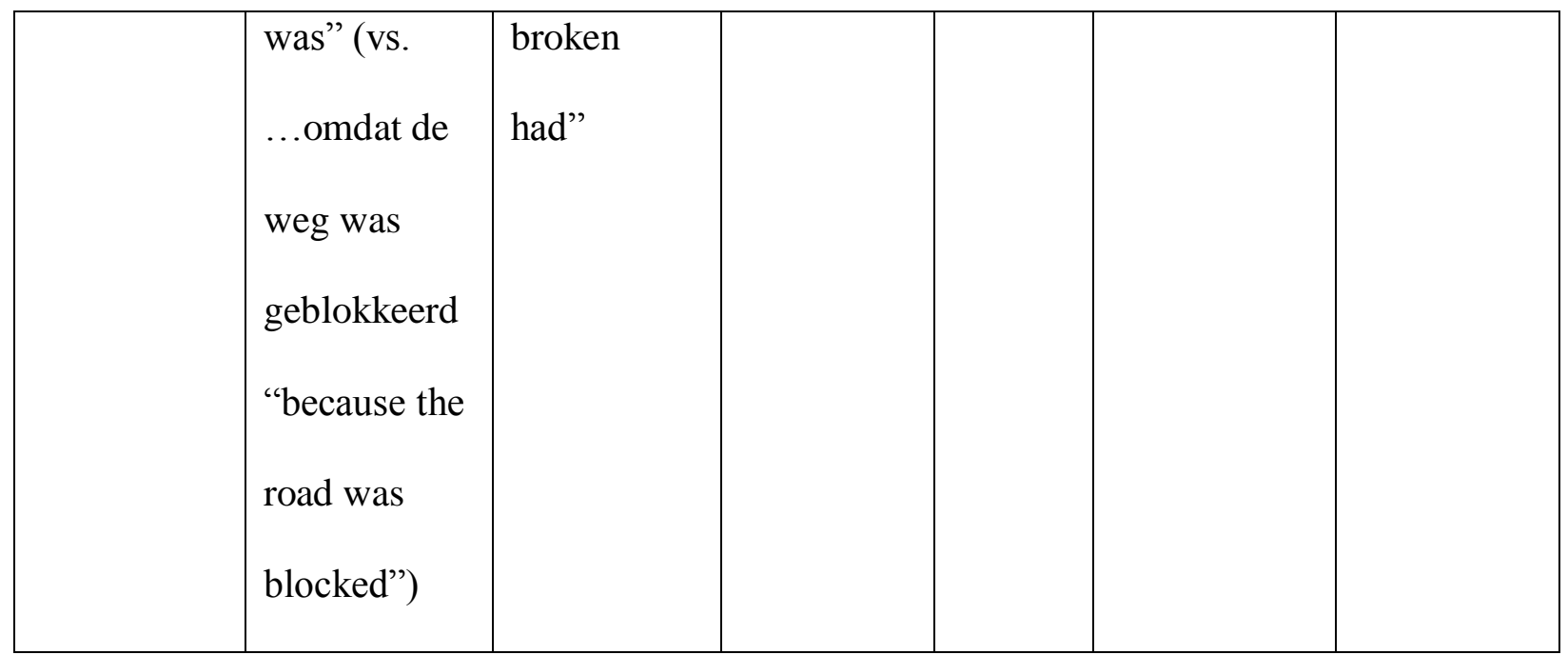

\section{Conclusion}

Priming is a powerful tool for studying linguistic representation (e.g., Branigan \& Pickering, 2017). In this paper, we questioned a key argument underlying claims that structural priming is based on tree structures devoid of meaning and morphology. In particular, we asked whether the priming Bock and Loebell (1990) observed between intransitive by-locatives and passives was driven by an abstract syntactic phrase structure, as has commonly been assumed (e.g., Bock \& Griffin, 2000; Branigan \& Pickering, 2017; Branigan et al., 1995; Chang et al., 2006; Pickering \& Branigan, 1998; Pickering et al., 2002; Pickering \& Ferreira, 2008; Rowland, Chang, Ambridge, Pine, \& Lieven, 2012). We found that priming did not occur when the locatives did not contain the preposition by. This forces us to reexamine the priming literature. In doing so, we observe that the loci of structural priming vary across constructions in ways which correspond to our theories of the representational bases of the alternations involved. These data highlight the importance of revisiting old conclusions with attention to the full range of factors that may be relevant for the selection of various types of grammatical patterns or constructions (for discussion, see Ziegler, Snedeker, \& Wittenberg, 2017). 


\section{Acknowledgments}

This research was supported by a Harvard Institute for Quantitative Social Science research grant to JZ. We thank Kay Bock for sharing her stimuli; Steven Pinker, the members of SnedLab, and audience at CUNY 2018 for helpful feedback and discussion; and Miriam Hauptman for assistance with coding. 


\section{References}

Baayen, R. H., Davidson, D. J., \& Bates, D. M. (2008). Mixed-effects modeling with crossed random effects for subjects and items. Journal of Memory and Language, 59(4), 390-412.

Baker, M., Johnson, K., \& Roberts, I. (1989). Passive arguments raised. Linguistic Inquiry, 20(2), 219-251.

Barr, D. J., Levy, R., Scheepers, C., \& Tily, H. J. (2013). Random effects structure for confirmatory hypothesis testing: Keep it maximal. Journal of Memory and Language, 68(3), 255-278.

Bates, D. M. (2010). lme4: Mixed-effects modeling with R. Available online at http://lme4.rforge.r-project.org/book/.

Bernolet, S., Hartsuiker, R. J., \& Pickering, M. J. (2007). Shared syntactic representations in bilinguals: Evidence for the role of word-order repetition. Journal of Experimental Psychology: Learning, Memory, and Cognition, 33(5), 931-949.

Bernolet, S., Hartsuiker, R. J., \& Pickering, M. J. (2009). Persistence of emphasis in language production: A cross-linguistic approach. Cognition, 112, 300-317.

Bernolet, S., Hartsuiker, R. J., \& Pickering, M. J. (2012). Effects of phonological feedback on the selection of syntax: Evidence from between-language syntactic priming. Bilingualism: Language and Cognition, 15(3), 503-516.

Bernolet, S., Hartsuiker, R. J., \& Pickering, M. J. (2013). From language-specific to shared syntactic representations: The influence of second language proficiency on syntactic sharing in bilinguals. Cognition, 127, 287-306.

Bock, K. (1986). Syntactic persistence in language production. Cognitive Psychology, 18, 355387. 
Bock, K. (1989). Closed-class immanence in sentence production. Cognition, 31, 163-186.

Bock, K., \& Griffin, Z. M. (2000). The persistence of structural priming: Transient activation or implicit learning? Journal of Experimental Psychology: General, 129(2), 177-192.

Bock, K., \& Loebell, H. (1990). Framing sentences. Cognition, 35, 1-39.

Bock, K., Loebell, H., \& Morey, R. (1992). From conceptual roles to structural relations: Bridging the syntactic cleft. Psychological Review, 99, 150-171.

Bolinger, D. (1967). Adjectives in English: Attribution and predication. Lingua, 18, 1-34.

Branigan, H. P. (2007). Syntactic priming. Language and Linguistics Compass, 1(1-2), 1-16.

Branigan, H. P., \& Pickering, M. J. (2017). An experimental approach to linguistic representation. Behavioral and Brain Sciences, 40, 1-61.

Branigan, H. P., Pickering, M. J., Liversedge, S. P., Stewart, A. J., \& Urbach, T. P. (1995). Syntactic priming: Investigating the mental representation of language. Journal of Psycholinguistic Research, 24(6), 489-506.

Bresnan, J. (1982). The passive in grammatical theory. In J. Bresnan (Ed.), The Mental Representation of Grammatical Relations (pp. 3-86). Cambridge, MA: The MIT Press.

Cai, Z. G., Pickering, M. J., \& Branigan, H. P. (2012). Mapping concepts to syntax: Evidence from structural priming in Mandarin Chinese. Journal of Memory and Language, 66(4), 833-849.

Cai, Z. G., Pickering, M. J., Yan, H., \& Branigan, H. P. (2011). Lexical and syntactic representations in closely related languages: Evidence from Cantonese-Mandarin bilinguals. Journal of Memory and Language, 65(4), 431-445. 
Cason, N., Astésano, C., \& Schön, D. (2015). Bridging music and speech rhythm: Rhythmic priming and audio-motor training affect speech perception. Acta Psychologica, 155, 4350.

Cason, N., \& Schön, D. (2012). Rhythmic priming enhances the phonological processing of speech. Neuropsychologia, 50(11), 2652-2658.

Chang, F., Bock, K., \& Goldberg, A. E. (2003). Can thematic roles leave traces of their places? Cognition, 90, 29-49.

Chang, F., Dell, G. S., \& Bock, K. (2006). Becoming syntactic. Psychological Review, 113(2), 234-272.

Chen, B., Jia, Y., Wang, Z., Dunlap, S., \& Shin, J.-A. (2013). Is word-order similarity necessary for cross-linguistic structural priming? Second Language Research, 29(4), 375-398.

Cho-Reyes, S., Mack, J. E., \& Thompson, C. K. (2016). Grammatical encoding and learning in agrammatic aphasia: Evidence from structural priming. Journal of Memory and Language, 91, 202-218.

Chomsky, N. (1965). Aspects of the theory of syntax. Cambridge, MA: The MIT Press.

Chomsky, N. (1994). Bare phrase structure. Cambridge, MA: The MIT Press.

Cleland, A. A., \& Pickering, M. J. (2003). The use of lexical and syntactic information in language production: Evidence from the priming of noun-phrase structure. Journal of Memory and Language, 49, 214-230.

Cornelis, L. (1996). English and Dutch: The passive difference. Language Sciences, 18(1-2), 247-264.

Croft, W. (2001). Radical construction grammar: Syntactic theory in typological perspective. Oxford, UK: Oxford University Press. 
Culicover, P. W. (1999). Syntactic nuts: Hard cases in syntax. Oxford: Oxford University Press.

Culicover, P. W., \& Jackendoff, R. (2005). Simpler syntax. Oxford: Oxford University Press.

Davies, M. (2008). The Corpus of Contemporary American English (COCA): 560+ million words, 1990-2017. Available online at: 〈https://www.english-corpora.org/coca/ $\rangle$.

Dehé, N. (2002). Particle verbs in English: Syntax, information structure, and intonation. Amsterdam: John Benjamins.

Desmet, T., \& Declercq, M. (2006). Cross-linguistic priming of syntactic hierarchical configuration information. Journal of Memory and Language, 54(4), 610-632.

De Sutter, G. (2009). Towards a multivariate model of grammar: The case of word order variation in Dutch clause final verb clusters. In A. Dufter, J. Fleischer, \& S. Guido (Eds.), Describing and Modeling Variation in Grammar (pp. 225-254). Berlin: De Gruyter Mouton.

Emonds, J. E. (1976). A transformational approach to English syntax: Root, structurepreserving, and local transformations. New York, NY: Academic Press.

Ferreira, V. S. (2003). The persistence of optional complementizer production: Why saying "that" is not saying "that" at all. Journal of Memory and Language, 48, 379-398.

Ferreira, V. S., \& Bock, K. (2006). The functions of structural priming. Language and Cognitive Processes, 21(7-8), 1011-1029.

Fillmore, C. J. (1968). The case for Case. In E. Bach \& R. T. Harms (Eds.), Universals in Linguistic Theory (pp. 1-88). New York: Holt, Rinehart, and Winston.

Fillmore, C. J. (1985). Frames and the semantics of understanding. Quaderni di Semantica, 6, 222-254. 
Fleischer, Z., Pickering, M. J., \& McLean, J. F. (2012). Shared information structure: Evidence from cross-linguistic priming. Bilingualism: Language and Cognition, 15, 568-579.

Fox Tree, J. E., \& Meijer, P. J. A. (1999). Building syntactic structure in speaking. Journal of Psycholinguistic Research, 28(1), 71-90.

Frazier, L., \& Fodor, J. D. (1978). The sausage machine: A new two-stage parsing model. Cognition, 6(4), 291-325.

Gámez, P. B., \& Vasilyeva, M. (2015). Exploring interactions between semantic and syntactic processes: The role of animacy in syntactic priming. Journal of Experimental Child Psychology, 138, 15-30.

Ginzburg, J., \& Sag, I. A. (2001). Interrogative investigations: The form, meaning, and use of English interrogatives. Chicago, IL: The University of Chicago Press..

Goldberg, A. E. (1995). Constructions: A construction grammar approach to argument structure. Chicago, IL: University of Chicago Press.

Goldberg, A. E. (2002). Surface generalizations: An alternative to alternations. Cognitive Linguistics, 13(4), 327-356.

Goldberg, A. E. (2006). Constructions at work: The nature of generalization in language. Oxford: Oxford University Press.

Green, G. M. (1974). Semantics and syntactic regularity. Bloomington, IN: Indiana University Press.

Gries, S. T. (1999). Particle movement: A cognitive and functional approach. Cognitive Linguistics, 10, 105-146.

Gries, S. T. (2005). Syntactic priming: A corpus-based approach. Journal of Psycholinguistic Research, 34(4), 365-399. 
Griffin, Z. M., \& Weinstein-Tull, J. (2003). Conceptual structure modulates structural priming in the production of complex sentences. Journal of Memory and Language, 49, 537-555.

Grimshaw, J. (1990). Argument structure. Cambridge, MA: The MIT Press.

Gureckis, T. M., Martin, J., McDonnell, J., Rich, A. S., Markant, D., Coenen, A., . . Chan, P. (2016). psiTurk: An open-source framework for conducting replicable behavioral experiments online. Behavioral Research Methods, 48(3), 829-842.

Hare, M. L., \& Goldberg, A. E. (1999). Structural priming: Purely syntactic? In M. Hahn \& S. C. Stones (Eds.), Proceedings of the 21st Annual Meeting of the Cognitive Science Society (pp. 208-211). Mahwah, NJ: Erlbaum.

Hartsuiker, R. J., Kolk, H. H. J., \& Huiskamp, P. (1999). Priming word order in sentence production. Quarterly Journal of Experimental Psychology, 52A, 129-147.

Hartsuiker, R. J., Pickering, M. J., \& Veltkamp, E. (2004). Is syntax separate or shared between languages? Cross-linguistic syntactic priming in Spanish-English Bilinguals. Psychological Science, 15(6), 409-414.

Hartsuiker, R. J., \& Westenberg, C. (2000). Word order priming in written and spoken sentence production. Cognition, 75, B27-B39.

Heydel, M., \& Murray, W. S. (2000). Conceptual effects in sentence priming: A cross-linguistic perspective. In M. De Vincenzi, \& V. Lombardo (Eds.), Cross-linguistic Perspectives on Language Processing (pp. 227-254). Dordrecht: Springer.

Hinterhölzl, R., \& Petrova, S. (Eds.). (2009). Information structure and language change: New approaches to word order variation in Germanic. Berlin: De Gruyter Mouton.

Jackendoff, R. S. (1972). Semantic interpretation in generative grammar. Cambridge, MA: The MIT Press. 
Jackendoff, R. (1975). Morphological and semantic regularities in the lexicon. Language, 51(3), 639-671.

Jackendoff, R. S. (1983). Semantics and cognition. Cambridge, MA: The MIT Press.

Jackendoff, R. (2002). Foundations of language. Oxford: Oxford University Press.

Jackendoff, R. (2007). A Parallel Architecture perspective on language processing. Brain Research, 1146, 2-22.

Jaeger, T. F. (2008). Categorical data analysis: Away from ANOVAs (transformation or not) and towards logit mixed models. Journal of Memory and Language, 59(4), 434-446.

Jaeger, T. F., \& Snider, N. E. (2013). Alignment as a consequence of expectation adaptation: Syntactic priming is affected by the prime's prediction error given both prior and recent experience. Cognition, 127(1), 57-83.

Jarosz, A. F., \& Wiley, J. (2014). What are the odds? A practical guide to computing and reporting Bayes factors. Journal of Problem Solving, 7(1), 2.

Jeffreys, H. (1961). Theory of probability (3rd ed.). Oxford, UK: Oxford University Press.

Koenig, J.-P., Mauner, G., \& Bienvenue, B. (2003). Arguments for adjuncts. Cognition, 89(2), 67-103.

Köhne, J., Pickering, M. J., \& Branigan, H. P. (2014). The relationship between sentence meaning and word order: Evidence from structural priming in German. The Quarterly Journal of Experimental Psychology, 67(2), 304-318.

Konopka, A. E., \& Bock, K. (2009). Lexical or syntactic control of sentence formulation? Structural generalizations from idiom production. Cognitive Psychology, 58, 68-101. Lakoff, G. (1970). Irregularity in syntax. New York: Holt, Rinehart, and Winston. 
Lakoff, G., \& Johnson, M. (1980). Metaphors we live by. Chicago, IL: The University of Chicago Press.

Lambrecht, K. (1994). Information structure and sentence form: Topic, focus, and the mental representations of discourse referents. Cambridge, UK: Cambridge University Press.

Langacker, R. (1987). Foundations of Cognitive Grammar I: Theoretical Prerequisites. Stanford: Stanford University Press.

Legate, J. A. (2014). Voice and v: Lessons from Acehnese. Cambridge, MA: The MIT Press. Levelt, W. J. M. (1993). Lexical access in speech production. In E. Reuland \& W. Abraham (Eds.), Knowledge and Language (pp. 241-251). Dordrecht: Springer.

MacDonald, M. C., Pearlmutter, N. J., \& Seidenberg, M. S. (1994). The lexical nature of syntactic ambiguity resolution. Psychological Review, 101, 676-703.

Mahowald, K., James, A., Futrell, R., \& Gibson, E. (2016). A meta-analysis of syntactic priming in language production. Journal of Memory and Language, 91, 5-27.

Messenger, K., Branigan, H. P., \& McLean (2011). Evidence for (shared) abstract structure underlying children's short and full passives. Cognition, 121, 268-274.

Messenger, K., Branigan, H. P., McLean, J. F., \& Sorace, A. (2012). Is young children's passive syntax semantically constrained? Evidence from syntactic priming. Journal of Memory and Language, 66, 568-587.

O’Donnell, T. J. (2015). Productivity and reuse in language: A theory of linguistic computation and storage. Cambridge, MA: The MIT Press.

Oehrle, R. T., Bach, E., \& Wheeler, D. (Eds.). (2012). Categorial grammars and natural language structures. New York, NY: Springer. 
Pappert, S., \& Pechmann, T. (2014). Priming word order by thematic roles: No evidence for an additional involvement of phrase structure. The Quarterly Journal of Experimental Psychology, 67(11), 2260-2278.

Pickering, M. J., \& Branigan, H. P. (1998). The representation of verbs: Evidence from syntactic priming in language production. Journal of Memory and Language, 39, 633-651.

Pickering, M. J., \& Ferreira, V. S. (2008). Structural priming: A critical review. Psychological Bulletin, 134(3), 427-459.

Pickering, M. J., Branigan, H. P., \& McLean, J. F. (2002). Constituent structure is formulated in one stage. Journal of Memory and Language, 46, 586-605.

Pollard, C., \& Sag, I. A. (1987). Information-based syntax and semantics. Stanford, CA: CSLI Publicartions.

Pollard, C., \& Sag, I. A. (1994). Head-driven phrase structure grammar. Chicago, IL: The University of Chicago Press.

Potter, M. C., \& Lombardi, L. (1998). Syntactic priming in immediate recall of sentences. Journal of Memory and Language, 38, 265-282.

Raftery, A. E. (1995). Bayesian model selection in social research. In P. V. Marsden (Ed.), Sociological Methodology (pp. 111-196). Cambridge, MA: Blackwell.

Rowland, C. F., Chang, F., Ambridge, B., Pine, J. M., \& Lieven, E. V. M. (2012). The development of abstract syntax: Evidence from structural priming and the lexical boost. Cognition, 125, 49-63.

Salamoura, A, \& Williams, J. N. (2007). Processing verb argument structure across languages: Evidence for shared representations in the bilingual lexicon. Applied Psycholinguistics, $28,627-660$. 
Schabes, Y., Abeillé, A., \& Joshi, A. K. (1988). Parsing strategies with "lexicalized" grammars: Application to Tree Adjoining Grammars. In D. Vargha (Ed.), Proceedings of the 12th International Conference on Computational Linguistics (pp. 578-583). Stroudsburg: Association for Computational Linguistics.

Scheepers, C. (2003). Syntactic priming of relative clause attachments: Persistence of structural configuration in sentence production. Cognition, 89(3), 179-205.

Schoonbaert, S., Hartsuiker, R. J., \& Pickering, M. J. (2007). The representation of lexical and syntactic information in bilinguals: Evidence from syntactic priming. Journal of Memory and Language, 56(2), 153-171.

Stefanowitsch, A. (2003). Constructional semantics as a limit to grammatical alternation: The two genitives of English. Topics in English Linguistics, 43, 413-444.

Swerts, M., \& van Wijk, C. (2005). Prosodic, lexico-syntactic, and regional influences on word order in Dutch verbal endgroups. Journal of Phonetics, 33(2), 243-262.

Tooley, K. M., Konopka, A. E., \& Watson, D. G. (2014). Can intonational phrase structure be primed (like syntactic structure)? Journal of Experimental Psychology: Learning, Memory, and Cognition, 40(2), 348-363.

Tooley, K. M., Konopka, A. E., \& Watson, D. G. (2018). Assessing priming for prosodic representations: Speaking rate, intonational phrase boundaries, and pitch accenting. Memory and Cognition, 46(4), 625-641.

Tooley, K. M., \& Traxler, M. J. (2010). Syntactic priming effects in comprehension: A critical review. Language and Linguistics Compass, 4(10), 925-937. 
Traxler, M. J., \& Tooley, K. M. (2012). Lexical and syntactic pirming in language comprehension. In N. Hsu \& Z. Schutt (Eds.), Psychology of Priming (pp. 79-100). New York, NY: Nova Science Publishers, Inc.

Trueswell, J. C., Tanenhaus, M. K., \& Garnsey, S. M. (1994). Semantic influences on parsing: Use of thematic role information in syntactic ambiguity resolution. Journal of Memory and Language, 33, 285-318.

Vernice, M., Pickering, M. J., \& Hartsuiker, R. J. (2012). Thematic emphasis in language production. Language and Cognitive Processes, 27(5), 631-664.

Wagenmakers, E. J. (2007). A practical solution to the pervasive problems of $p$ values. Psychonomic Bulletin \& Review, 14(5), 779-804.

Yi, E., \& Koenig, J.-P. (2016). Why verb meaning matters to syntax. In J. Fleischhauer, A. Latrouite, \& R. Osswald (Eds.), Explorations of the Syntax-Semantics Interface (pp. 5776). Düsseldorf: Düsseldorf University Press.

Ziegler, J. (2019). The building blocks of meaning: Psycholinguistic evidence on the nature of verb argument structure (Doctoral dissertation). Harvard University, Cambridge, MA.

Ziegler, J., Morato, R., \& Snedeker, J. (in press). Priming semantic structure in Brazilian Portuguese. Journal of Cultural Cognitive Science.

Ziegler, J., \& Snedeker, J. (2018). How broad are thematic roles? Evidence from structural priming. Cognition, 179, 221-240.

Ziegler, J., \& Snedeker, J. (2019). The use of syntax and information structure during language comprehension: Evidence from structural priming. Language, Cognition, and Neuroscience, 34(3), 365-384. 
Ziegler, J., Snedeker, J., \& Wittenberg, E. (2017). Priming is swell, but it's far from simple (commentary on Branigan \& Pickering’s “An experimental approach to linguistic representation"). Behavioral and Brain Sciences, 40, 44-45.

Ziegler, J., Snedeker, J., \& Wittenberg, E. (2018). Event structures drive semantic structural priming, not thematic roles: Evidence form idioms and light verbs. Cognitive Science, 42(8), 2918-2949. 
Appendix A. Prime sentences.

\begin{tabular}{|c|c|}
\hline \multicolumn{2}{|r|}{ *a=Passive; $\mathrm{b}=$ Active; $\mathrm{c}=B y$-locative; $\mathrm{d}=$ Non- $b y$-locative } \\
\hline $1 \mathrm{a}$ & The senator was awed by the statue. \\
\hline $1 b$ & The senator unveiled the statue. \\
\hline $1 \mathrm{c}$ & The senator was speaking by the statue. \\
\hline $1 d$ & The senator has spoken about the statue. \\
\hline $2 \mathrm{a}$ & The woman was stung by the jellyfish. \\
\hline $2 b$ & The woman caught the jellyfish. \\
\hline $2 \mathrm{c}$ & The woman was swimming by the jellyfish. \\
\hline $2 \mathrm{~d}$ & The woman has swum into the jellyfish. \\
\hline $3 a$ & The escaping prisoner was illuminated by the guard tower. \\
\hline $3 b$ & The escaping prisoner avoided the guard tower. \\
\hline $3 c$ & The escaping prisoner was hiding by the guard tower. \\
\hline $3 d$ & The escaping prisoner has hidden below the guard tower. \\
\hline $4 \mathrm{a}$ & The foreigner was confused by the blinking traffic light. \\
\hline $4 b$ & The foreigner misunderstood the blinking traffic light. \\
\hline $4 \mathrm{c}$ & The foreigner was loitering by the blinking traffic light. \\
\hline
\end{tabular}




\begin{tabular}{|c|l|}
\hline $4 d$ & The foreigner has loitered at the blinking traffic light. \\
\hline $5 \mathrm{a}$ & The Dalmatian was pursued by the fire truck. \\
\hline $5 \mathrm{~b}$ & The Dalmatian chased the fire truck. \\
\hline $5 \mathrm{c}$ & The Dalmatian was running by the fire truck. \\
\hline $5 \mathrm{~d}$ & The Dalmatian has run around the fire truck. \\
\hline $6 \mathrm{a}$ & The secretary was splashed by the drinking fountain. \\
\hline $6 \mathrm{~b}$ & The secretary cleaned the drinking fountain. \\
\hline $6 \mathrm{c}$ & The secretary was tripping by the drinking fountain. \\
\hline $6 \mathrm{~d}$ & The secretary has tripped near the drinking fountain. \\
\hline $7 \mathrm{a}$ & The construction worker was hit by the bulldozer. \\
\hline $7 \mathrm{c}$ & The construction worker drove the bulldozer. \\
\hline 7c & The construction worker was digging by the bulldozer. \\
\hline $8 \mathrm{~b}$ & The new graduate joined the software company. \\
\hline $\mathrm{y}$ & The new graduate was hired by the software company. \\
\hline
\end{tabular}




\begin{tabular}{|c|l|}
\hline $8 \mathrm{~d}$ & The new graduate has driven around the software company. \\
\hline $9 \mathrm{a}$ & The ship was damaged by the pier. \\
\hline 9b & The ship approached the pier. \\
\hline 9c & The ship was docking by the pier. \\
\hline 9d & The ship has docked at the pier. \\
\hline 10a & The minister was cut by the broken stained glass window. \\
\hline 10b & The minister fixed the broken stained glass window. \\
\hline 10c & The minister was praying by the broken stained glass window. \\
\hline 10d & The minister has prayed below the broken stained glass wind \\
\hline $11 \mathrm{a}$ & The engineers were appalled by the monument. \\
\hline $11 \mathrm{~b}$ & The engineers criticized the monument. \\
\hline $11 \mathrm{c}$ & The engineers were conferring by the monument. \\
\hline $12 \mathrm{~d}$ & The engineers have conferred at the monument. \\
\hline 12b & The lumberjack was struck by the giant redwood tree. \\
\hline
\end{tabular}




\begin{tabular}{|c|l|}
\hline $12 \mathrm{~d}$ & The lumberjack has rested inside the giant redwood tree. \\
\hline $13 \mathrm{a}$ & The students were bankrupted by the new sports complex. \\
\hline $13 \mathrm{~b}$ & The students tried the new sports complex. \\
\hline $13 \mathrm{c}$ & The students were working by the new sports complex. \\
\hline $13 \mathrm{~d}$ & The students have worked in the new sports complex. \\
\hline $14 \mathrm{a}$ & The 747 was radioed by the airport control tower. \\
\hline $14 \mathrm{~b}$ & The 747 radioed the airport control tower. \\
\hline $14 \mathrm{c}$ & The 747 was landing by the airport control tower. \\
\hline $14 \mathrm{~d}$ & The 747 has landed near the airport control tower. \\
\hline $15 \mathrm{a}$ & The missing geologist was smothered by the volcano. \\
\hline $15 \mathrm{~b}$ & The missing geologist underestimated the volcano. \\
\hline $15 \mathrm{c}$ & The missing geologist was wandering by the volcano. \\
\hline $15 \mathrm{~d}$ & The missing geologist has wandered into the volcano. \\
\hline $16 \mathrm{a}$ & The Cub Scouts were warmed by the campfire. \\
\hline $16 \mathrm{~b}$ & The Cub Scouts enjoyed the camp fire. \\
\hline The Cub Scouts were singing by the campfire. \\
\hline
\end{tabular}




\begin{tabular}{|c|l|}
\hline $16 \mathrm{~d}$ & The Cub Scouts have sung around the campfire. \\
\hline $17 \mathrm{a}$ & The princess was delighted by the palace's old gate. \\
\hline $17 \mathrm{~b}$ & The princess renovated the palace's old gate. \\
\hline $17 \mathrm{c}$ & The princess was daydreaming by the palace's old gate. \\
\hline $17 \mathrm{~d}$ & The princess has daydreamed under the palace's old gate. \\
\hline $18 \mathrm{a}$ & The stockbroker was sued by the client. \\
\hline $18 \mathrm{~b}$ & The stockbroker impressed the client. \\
\hline $18 \mathrm{c}$ & The stockbroker was sitting by the client. \\
\hline $18 \mathrm{~d}$ & The stockbroker has sat opposite the client. \\
\hline $19 \mathrm{a}$ & The businessman was paged by the airline ticket counter. \\
\hline $19 \mathrm{~b}$ & The businessman left the airline ticket counter. \\
\hline $19 \mathrm{c}$ & The businessman was waiting by the airline ticket counter. \\
\hline $20 \mathrm{c}$ & The businessman has waited behind the airline ticket count. \\
\hline $20 \mathrm{~b}$ & The scientist examined the apple tree. \\
\hline
\end{tabular}




\begin{tabular}{|c|l|}
\hline $20 \mathrm{~d}$ & The scientist has slept under the apple tree. \\
\hline $21 \mathrm{a}$ & The surfer was excited by the stormy sea. \\
\hline $21 \mathrm{~b}$ & The surfer watched the stormy sea. \\
\hline $21 \mathrm{c}$ & The surfer was sprinting by the stormy sea. \\
\hline $21 \mathrm{~d}$ & The surfer has sprinted along the stormy sea. \\
\hline $22 \mathrm{a}$ & The patron was annoyed by the jukebox in the bar. \\
\hline $22 \mathrm{~b}$ & The patron destroyed the jukebox in the bar. \\
\hline $22 \mathrm{c}$ & The patron was drinking by the jukebox in the bar. \\
\hline $22 \mathrm{~d}$ & The patron has drunk at the jukebox in the bar. \\
\hline $23 \mathrm{a}$ & The bag lady was caught by the revolving door. \\
\hline $23 \mathrm{~b}$ & The bag lady stopped the revolving door. \\
\hline $23 \mathrm{c}$ & The bag lady was falling by the revolving door. \\
\hline $23 \mathrm{~d}$ & The bag lady has fallen in the revolving door. \\
\hline $24 \mathrm{a}$ & The dictator was overthrown by the general. \\
\hline $24 \mathrm{~b}$ & The dictator trusted the general. \\
\hline The dictator was standing by the general. \\
\hline
\end{tabular}




\begin{tabular}{|l|l|}
\hline $24 \mathrm{~d}$ & The dictator has stood behind the general. \\
\hline $25 \mathrm{a}$ & The children were deafened by the church organ. \\
\hline $25 \mathrm{~b}$ & The children disliked the church organ. \\
\hline $25 \mathrm{c}$ & The children were playing by the church organ. \\
\hline $25 \mathrm{~d}$ & The children have played beside the church organ. \\
\hline $26 \mathrm{a}$ & The fishermen were startled by the buoy. \\
\hline $26 \mathrm{~b}$ & The fishermen damaged the buoy. \\
\hline $26 \mathrm{c}$ & The fishermen were fishing by the buoy. \\
\hline $26 \mathrm{~d}$ & The fishermen have fished at the buoy. \\
\hline $27 \mathrm{a}$ & The young woman was calmed by the lake. \\
\hline $27 \mathrm{~b}$ & The young woman admired the lake. \\
\hline $27 \mathrm{c}$ & The young woman was walking by the lake. \\
\hline $28 \mathrm{~d}$ & The young woman has walked along the lake. \\
\hline $28 \mathrm{a}$ & The bum was scratched by the bushes. \\
\hline
\end{tabular}




\begin{tabular}{|l|l|}
\hline $28 \mathrm{~d}$ & The bum has napped in the bushes. \\
\hline $29 \mathrm{a}$ & The dog was protected by the fence. \\
\hline $29 \mathrm{~b}$ & The dog jumped the fence. \\
\hline $29 \mathrm{c}$ & The dog was barking by the fence. \\
\hline $29 \mathrm{~d}$ & The dog has barked behind the fence. \\
\hline $30 \mathrm{a}$ & The grandmother was pleased by the flowers. \\
\hline $30 \mathrm{~b}$ & The grandmother liked the flowers. \\
\hline $30 \mathrm{c}$ & The grandmother was sketching by the flowers. \\
\hline $30 \mathrm{~d}$ & The grandmother has sketched near the flowers. \\
\hline $31 \mathrm{a}$ & The councilman was impressed by the new building. \\
\hline $31 \mathrm{~b}$ & The councilman opened the new building. \\
\hline $31 \mathrm{c}$ & The councilman was strolling by the new building. \\
\hline $31 \mathrm{~d}$ & The councilman has strolled past the new building. \\
\hline $32 \mathrm{a}$ & The nymphs were soaked by the waterfall. \\
\hline $32 \mathrm{~b}$ & The nymphs saw the waterfall. \\
\hline $32 \mathrm{c}$ & The nymphs were bathing by the waterfall. \\
\hline
\end{tabular}


32d The nymphs have bathed under the waterfall. 
Appendix B. Target pictures.

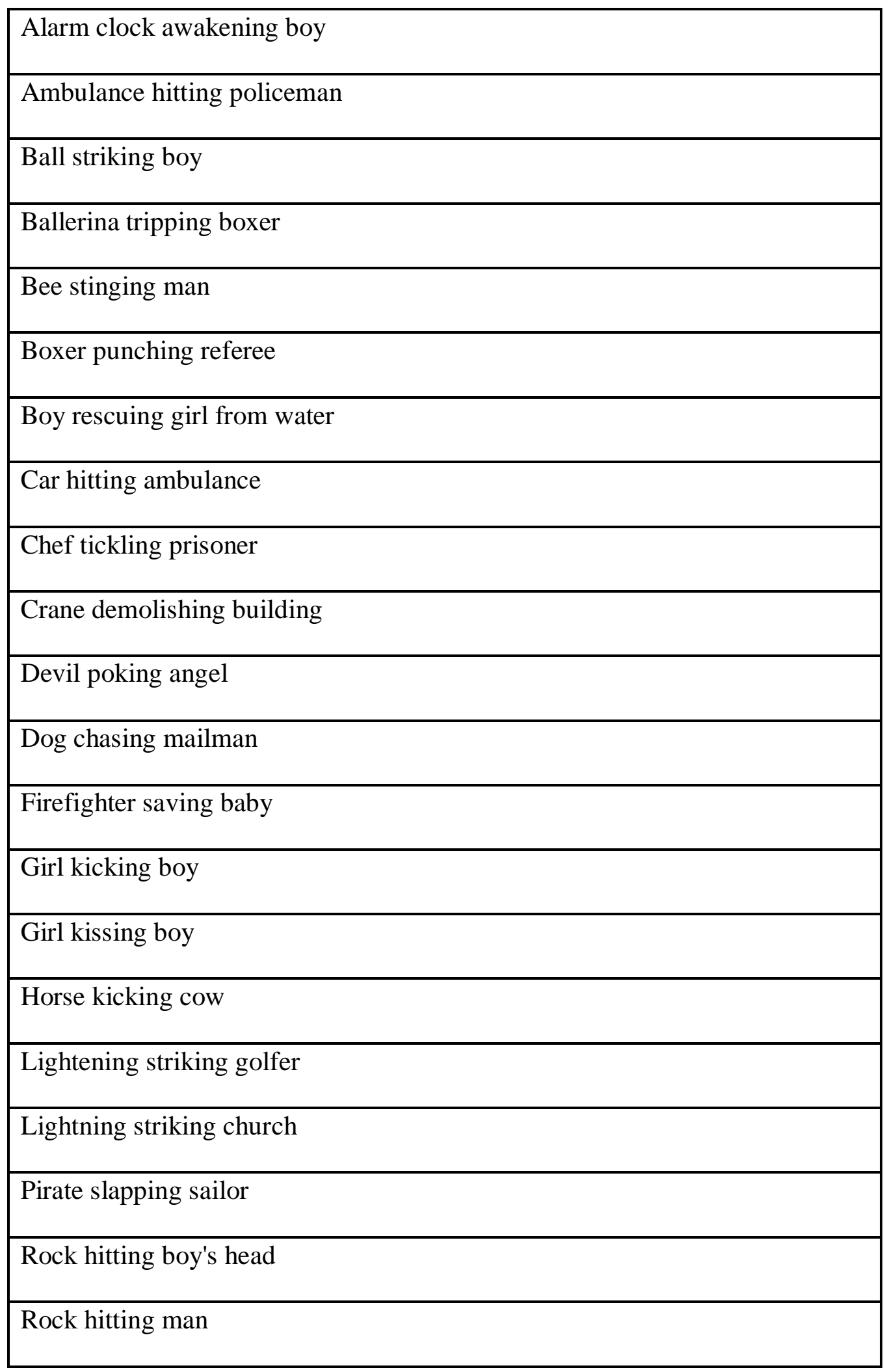




\begin{tabular}{|l|}
\hline Sailor kicking soldier \\
\hline Shark scaring boy \\
\hline Tornado destroying barn \\
\hline Toy startling little girl \\
\hline Train hitting truck \\
\hline Truck towing car \\
\hline Wave engulfing boy \\
\hline Wave hitting woman \\
\hline Whale swallowing man \\
\hline Wind blowing man's hat off \\
\hline Woman pushing boy in sled \\
\hline
\end{tabular}


Appendix C. Supplementary material.

The data associated with this article, including COCA frequencies and pilot results, can be found at https://www.doi.org/10.17605/OSF.IO/K3TNJ. 